\title{
ENTOMOLOGY
}

\section{Lixus algirus L. (Coleoptera: Curculionidae): biology, population fluctuation, infestation as affected by varieties, location, and planting dates in Morocco}

\author{
N. Ait Taadaouit, ${ }^{1,2}$ K. El Fakhouri, ${ }^{1}$ A. Sabraoui, ${ }^{1}$ L. Rohi, ${ }^{2}$ M. El Bouhssini ${ }^{1}$ \\ ${ }^{1}$ Entomology Laboratory, International Center for Agricultural Research in the Dry Areas (ICARDA), Rabat Institutes, \\ Rabat; ${ }^{2}$ Laboratory of Ecology and Environment, Faculty of Sciences Ben M'sik, University Hassan II of Casablanca, \\ Casablanca, Morocco
}

\begin{abstract}
The stem borer, Lixus algirus L. (Coleoptera: Curculionidae) is the major insect pest of faba bean in the Mediterranean region. This study investigates the field biology and fluctuation of $L$. algirus at Douyet research Station in Morocco during two cropping seasons 2014-2015 and 2015-2016 using two local faba bean varieties. The influence of sowing dates and varieties on the damage caused by $L$. algirus was investigated over different locations and seasons using a split-plot design. The overwintering adults appear in the field from February by feeding over the leaves of faba bean plants. Eggs are laid from Mid-February through late
\end{abstract}

Correspondence: Karim El Fakhouri, Entomology Laboratory, International Center for Agricultural Research in the Dry Areas (ICARDA), Rabat Institutes, Rabat, Morocco.

Tel.: +21.2677504124

E-mail: K.El-Fakhouri@cgiar.org

Key words: Faba bean stem borer, Population dynamics, damage, climatic factors, cultural practices, Morocco

Contributions: NA and KE contributed equally as first authors; the other authors contributed equally.

Conflict of interest: No potential conflict of interest was reported by the authors.

Funding: This research was partially funded by the project "IndiaMorocco Food Legumes Initiative - Morocco Component OCP Foundation, ID: 100161”.

Received for publication: 28 August 2020.

Revision received: 26 January 2021

Accepted for publication: 31 January 2021.

${ }^{\circ}$ Copyright: the Author(s), 2021

Licensee PAGEPress, Italy

Journal of Entomological and Acarological Research 2021; 53:9324

doi:10.4081/jear:2021.9324

This article is distributed under the terms of the Creative Commons Attribution Noncommercial License (by-nc 4.0) which permits any noncommercial use, distribution, and reproduction in any medium, provided the original author(s) and source are credited.
April and mostly during March. The egg peak ranged from 0.75 to 1.1 eggs per plant. The number of larvae increases during March and peaked in April. The larval peaks ranged between 0.45 to 1.5 larvae per plant. The larval development takes an average of 42 days. Pupation lasts about 21 days within stems. Adults emerged in early June. Life cycle duration was 80 days. One generation of L. algirus was recorded on faba bean varieties in Morocco. The mean number of eggs showed a positive correlation with total rainfall. The number of pupae and relative humidity was negatively correlated. Peach and almond leaves were the most preferred by the newely emerged $L$. algirus adult during the summer and early autumn period. Planting dates did not affect $L$. algirus infestation levels over all varieties tested and locations.

\section{Introduction}

The faba bean (Vicia faba L.) is one of the most winter-sown legume crops in the Mediterranean region (Manzoor, 2013). In Morocco, this crop is considered among the most ancient crops and the most important food legume crop. For instance, faba bean plays a key role in the crop rotation system with cereals to improve soil fertility. Moreover, the diversification of cropping systems is leading to decreased disease, pests and weed build up and potentially increased biodiversity, and providing food and feed rich in protein (Amanuel et al., 2000; Crepona et al., 2010; Maalouf et al., 2013).

Unfortunately, the average yields of faba beans in Morocco remain 58\% lower than the world average (FAO, 2016). Nowadays, drought, Orobanche, Botrytis, stem nematodes, and insect damage have severely affected the productivity and availability of this crop (Sakr, 1991; Yigezu et al., 2018).

In Morocco, $V$. faba is attacked by several insect pests, which often cause extensive damage. Aphids Aphis fabae and A. craccivo$r a$, Sitona weevils, Sitona lineatus L., species of Bruchus and Callosobruchus and Lixus algirus are the most frequent insects found on faba bean at different plant phonological stages (Hoffmann, 1954; Bardner, 1983; Sakr, 1991; Weigand \& Bishara, 1991).

The stem borer weevil, L. algirus is an important insect pest of faba bean in southern Europe, the Middle East, and the Mediterranean region including North Africa (Diekmann, 1982; Weigand \& Bishara, 1991). The significant damage is mainly caused by the larval stage causing the leaf yellowing, wilting, and drying of the plants, affecting its growth and yield (Liotta, 1963; 
Chakir, 1992; Khan et al., 2010 ). In Morocco, the stem borer is a very destructive pest, with mean infestation rate of $75 \%$ (Diekmann, 1982). Despite the economic importance of this insect pest, there is little information available on its population dynamic and the methods for its control.

Several cultural practices can be useful in reducing insect infestations, which include sowing dates, seed rates, and fertilization, clean seed, plowing, crop rotation tactic and intercropping to produce the healthiest crop possible. Adjusting sowing dates is one of the most important cultural practices that can help to escape pest occurrence or avoid the most vulnerable stages. This safe and sustainable tool has been incorporated successfully for many IPM programs around the world for decades (Dara, 2019).

The objectives of this study were 1) to investigate the field biology and the population fluctuations of the faba bean stem borer and 2) to evaluate the effects of planting dates and varieties on the damage caused by stem borer at different locations.

\section{Materials and methods}

\section{Biology and dynamic study of faba bean stem borer}

\section{Experimental site}

The experiments were conducted in two faba bean fields at Douyet Experimental Station INRA-CRRA Meknes, Morocco, located $12 \mathrm{~km}$ of Fez city (Saïs region), following the geographical coordinates $\left(33^{\circ} 03^{\prime} 59^{\prime \prime} \mathrm{N}, 7^{\circ} 53^{\prime} 05^{\prime \prime} \mathrm{W}\right)$ and $\left(33^{\circ} 04^{\prime} 05.0^{\prime \prime} \mathrm{N}\right.$ $7^{\circ} 53$ '13.6”'W) with an elevation of $416 \mathrm{~m}$.

Two local faba bean varieties Defes ( $V$. faba major) and Alfia ( $V$. faba minor) were planted on December 10, 2015, and December 15, 2016, following a Split Plot design with four replications. Each plot had five rows of 5-meter length and $0.6 \mathrm{~m}$ between rows, with a seeding rate of $100 \mathrm{~kg} / \mathrm{ha}$. No insecticide was applied during the crop-growing seasons.

\section{Sampling insect populations}

Population dynamics of L. algirus were conducted from early February to Mid - June in 2015 and 2016. Sampling was performed twice a week by tearing randomly 20 plants from each plot and brought to the laboratory for evaluation. L. algirus adults were manually checked on flowers, leaves, and other plant parts. Direct observations of mating behaviour were made, with recording on number of perforations per stems. In the laboratory, the faba bean plants sampled were dissected carefully with scissors under a binocular. The plants were checked for egg laying, adult exit hole and, presence of larva or pupa inside the stem or its exudates. All stages of the weevil were examined with an eyepiece micrometric scale using the stereomicroscope Motic SMZ-140, length and width values of each insect stage are given in millimeters.

\section{The duration of developmental stages and sex ratio}

During the mating period of L. algirus, each couple was placed in Petri dishes of $15 \mathrm{~cm}$ in diameter with two parts of the faba bean stems under laboratory conditions $\left(25 \pm 1^{\circ} \mathrm{C} ; 70-75 \%\right.$ relative humidity (RH); a photoperiod ranging from $10: 14 \mathrm{~h}$ to $14: 10$ (L:D). Each egg laid was placed inside a part of faba bean stem, which was closed at the ends by the parafilm. The eggs were checked daily until they reached the adult stage.

The duration of insect developmental stages (egg, larva, and pupa) were recorded by observing 100 individuals for each stage (20 individuals in 5 replications).
Sex ratio was determined on L. algirus that emerged from field infested faba bean. The most reliable sex character used to separate the males and females of $L$. algirus is the length of the rostrum. Following Hoffmann (1954), the female rostrum is $1 / 2$ longer than the prothorax or $1 / 4$ longer (male).

\section{Diapause}

After faba bean harvest, different surveys were conducted around faba bean fields in the region to identify the second host of the weevil. Various fruit trees and weeds belonging to different families were checked during summer and autumn as mentioned by Chakir (1992) and Liotta (1963).

\section{Feeding preference tests of new generation adults}

Feeding preference tests of the L. algirus for different tree species was tested in a closed plastic box $(230 \mathrm{~mm} \times 450 \mathrm{~mm} \times 700$ $\mathrm{mm})$ under laboratory conditions $\left(25 \pm 1^{\circ} \mathrm{C} ; 70-75 \%\right.$ relative humidity $(\mathrm{RH})$; a photoperiod of $13: 11 \mathrm{~h}(\mathrm{~L}: \mathrm{D})$, containing a moistened filter paper and one single leaf with a similar leaf area. The host plants tested were six trees belonging to Rosaceae family (Prunus persica L., Prunus dulcis M., Prunus armeniaca L., Pyrus communis L., Prunus cerasus L., Malus domestica B); the walnut tree, Juglans regia L. (Juglandaceae); olive tree, Olea europaea L. (Oleaceae); the Pistachio tree, Pistacia vera L. (Anacardiaceae). A group of 10 newly emerged $L$. algirus adults were allowed to feed for $72 \mathrm{~h}$ $\left(25 \pm 2^{\circ} \mathrm{C}\right)$ under laboratory conditions, after a starvation period of 3 days. The control treatment consisted of faba bean leaves and each choice test was replicated 6 times over 4 weeks. Relative preference of individual $L$. algirus was calculated by counting the number of feeding notches (FN) per leaf of different plant species.

\section{Effects of planting date, variety, and location on faba bean stem borer infestation}

Two Moroccan local varieties Defes and the Alfia were planted in three different regions representing different climatic zones. The varieties were planted in rows of $4 \mathrm{~m}$ long and $0.6 \mathrm{~m}$ spacing between rows, with a seeding rate of $100 \mathrm{~kg} / \mathrm{ha}$. The experiments were laid out following a split-plot design with four replications. Three different sowing dates were used, October 26, November 18 and December 23, 2016 at Marchouch experimental Station of the International Center for Agricultural Research in the Dry Areas (ICARDA), located $70 \mathrm{~km}$ South of Rabat in Morocco. At Douyet station, two planting dates were used,7 November and December 22, 2016. During the $2017 / 2018$ cropping season, two different sowing dates were used at Marchouch Station on December 9 and 27, 2017. In Allal Tazi Research Station located at $30 \mathrm{~km}$ from Kenitra city (Gharb region), two dates were used, December 2 and 29, 2017. Normal agronomic practices were followed for growing the crop. No insecticide or fertilizer treatment were applied on the trials.

At harvest time, 10 plants were randomly sampled from each plot and checked in the laboratory as described above.

\section{Statistical analysis}

ANOVA was analysed by using GenStat 20th edition. Insect counts and the number of infested plants in a plot were subjected to square root transformation to normalize variances before analysis. Mean numbers of each insect stages for each variety per month were separated using Newman-Keul's test at $p \leq 0.05$. For the feeding preference, the number of feeding notches were analysed using one-way ANOVA followed by Newman-Keul's test at $\mathrm{p} \leq 0.05$.

The data on the effect of planting date, variety and station on square root number of infested plants by faba bean stem borer were analysed for split plot factorial design and differences among var- 
ious means were determined using Tukey's HSD test. Correlation analysis was carried out to relate immature stages counts to meteorological data. The agrometeorological data of Douyet Station was obtained using the web meteoblue (Meteoblue, 2018).

\section{Results}

\section{Biology and dynamic populations of $L$. algirus during 2015 and 2016}

\section{Adult emergence}

Adults are large beetles 15-22 mm long (Table 1) and have cylindrical and slender elongated shape. The antennae and tarsus are ferruginous. They are dark and covered with a yellowish pruinosity resembling pollen. Rostrum is fairly arched, a cylindrical, slightly swollen at the level of the antenna insertion. Females have longer rostrum than males. Adults are an excellent flyer and can travel long distances to look for feeding sources. During the days, the adults start feeding on the leaves of faba bean plants. They spend almost all their time hiding among leaves of the faba bean plants near the ground. Sometimes they climb to the higher parts of the plant.

This weevil began to appear in both major and minor faba bean fields on 09 February 2015 (Figures 1 and 2) under photoperiod 11L:13D and mean temperature $09^{\circ} \mathrm{C}$ (Table 1). In the second year, the first adult was captured on 04 February 2016 (Figures 3 and 4) under photoperiod 11L:13D and mean temperature of $13^{\circ} \mathrm{C}$ (Table 2).

\section{Mating and oviposition}

Females feed for a few days before becoming sexually active and start oviposition shortly after mating during the early flowering stage of the faba bean plant. The females bore holes (Figure $3 \mathrm{E})$ into and lay eggs in the lower part of the stems and rarely in

Table 1. Body measurements (mm) of instar larvae of Lixus algirus.

\begin{tabular}{lccc} 
Larva length $(\mathrm{mm})$ & Range & Range \\
$10.77 \pm 0.25$ & 1.5 to 28.4 & $2.09 \pm 0.03$ & 0.8 to 4.5 \\
\hline
\end{tabular}

Table 2. Duration (days \pm S.E) of different stages of $L$. algirus on faba bean varieties during 2015 and 2016.

\begin{tabular}{lccc} 
Stage & Average (days \pm SE) & Max \\
Egg & $12.8 \pm 0.11$ & 11 & 15 \\
Larva & $42.03 \pm 2.82$ & 37 & 48 \\
\hline Pupa & $21.73 \pm 0.21$ & 19 & 24 \\
Adult within stem & $2.76 \pm 0.13$ & 2 & 4 \\
\hline Egg to adult & 79.32 & 69 & 91 \\
\hline
\end{tabular}

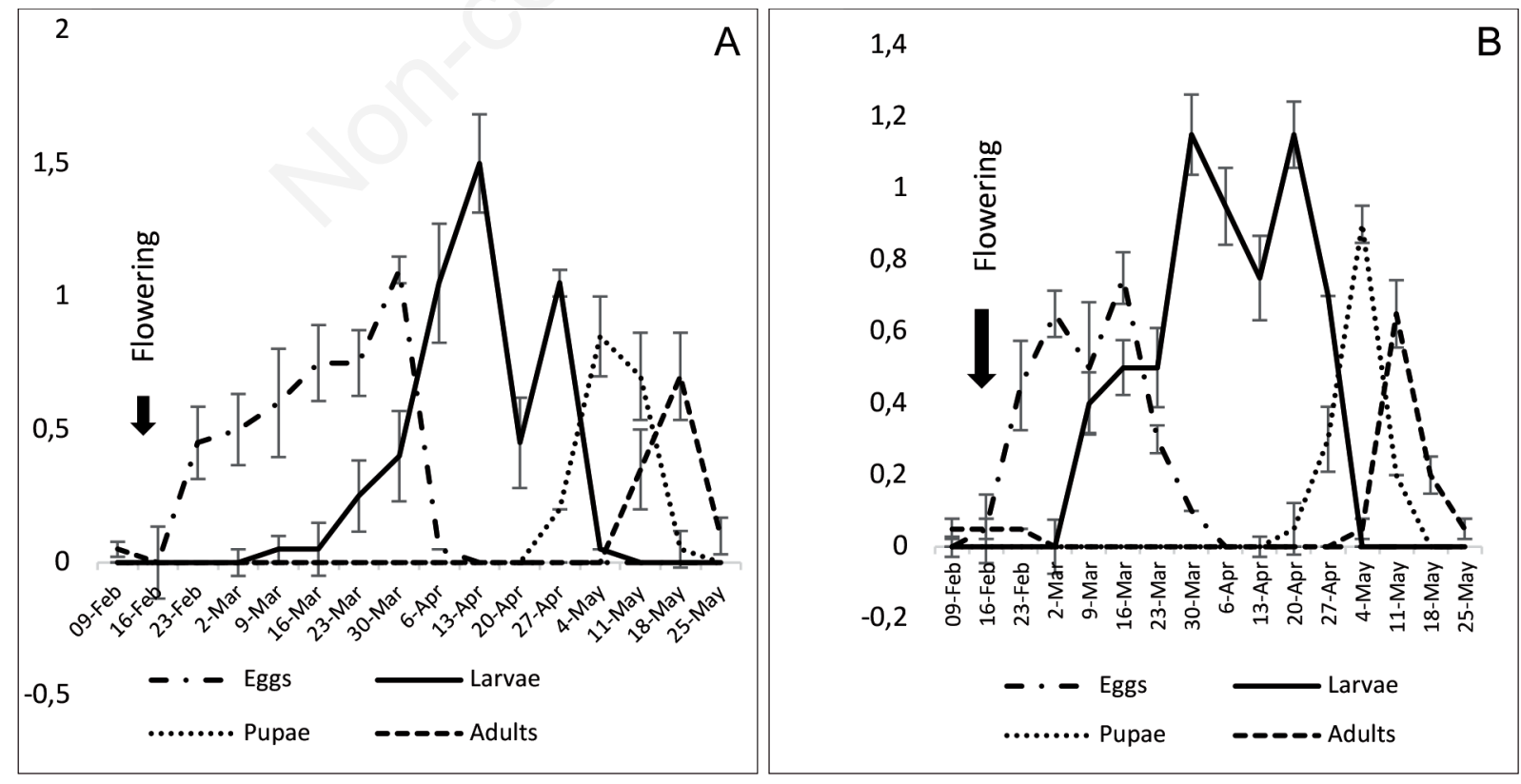

Figure 1. Mean number of eggs, larvae, pupae, and adults of $L$. algirus per 20 plants recorded on the local large-seeded variety Defes (Vicia faba var. major) (A) and small-seeded variety Alfia (Vicia faba var. minor) (B) during 2015, Douyet Station. 
the upper half of the faba bean plant. The L. algirus females spend more time during the day searching for a suitable oviposition site among different stems using antennal movement and antennal rotation to secure the best conditions for the larvae development. Fresh laid eggs are oval and ranged from 1 to $2 \mathrm{~mm}$ (Figure $3 \mathrm{~A}$ ), creamy white and then become yellowish, smooth, transparent. Several perforated stems showed laying holes, but only one egg found within the stem. The eggs hatch over a period ranging from 11 to 15 days.
The oviposition period is extended from Mid-February to late April. The number of the egg laying increased gradually with increasing temperature and photoperiod, to reach the peaks during March, as more adult weevils become active.

During 2015, the eggs are recorded in the local large-seeded variety Defes from 23 February to 6 April and peaked with $0.75 \pm 0.20$ eggs per plant or 3 stems and $1.1 \pm 0.12$ eggs per plant on March 23 and 30, respectively (Figure 1A). While the eggs are laid in the local small-seeded variety Alfia from 16 February to 30
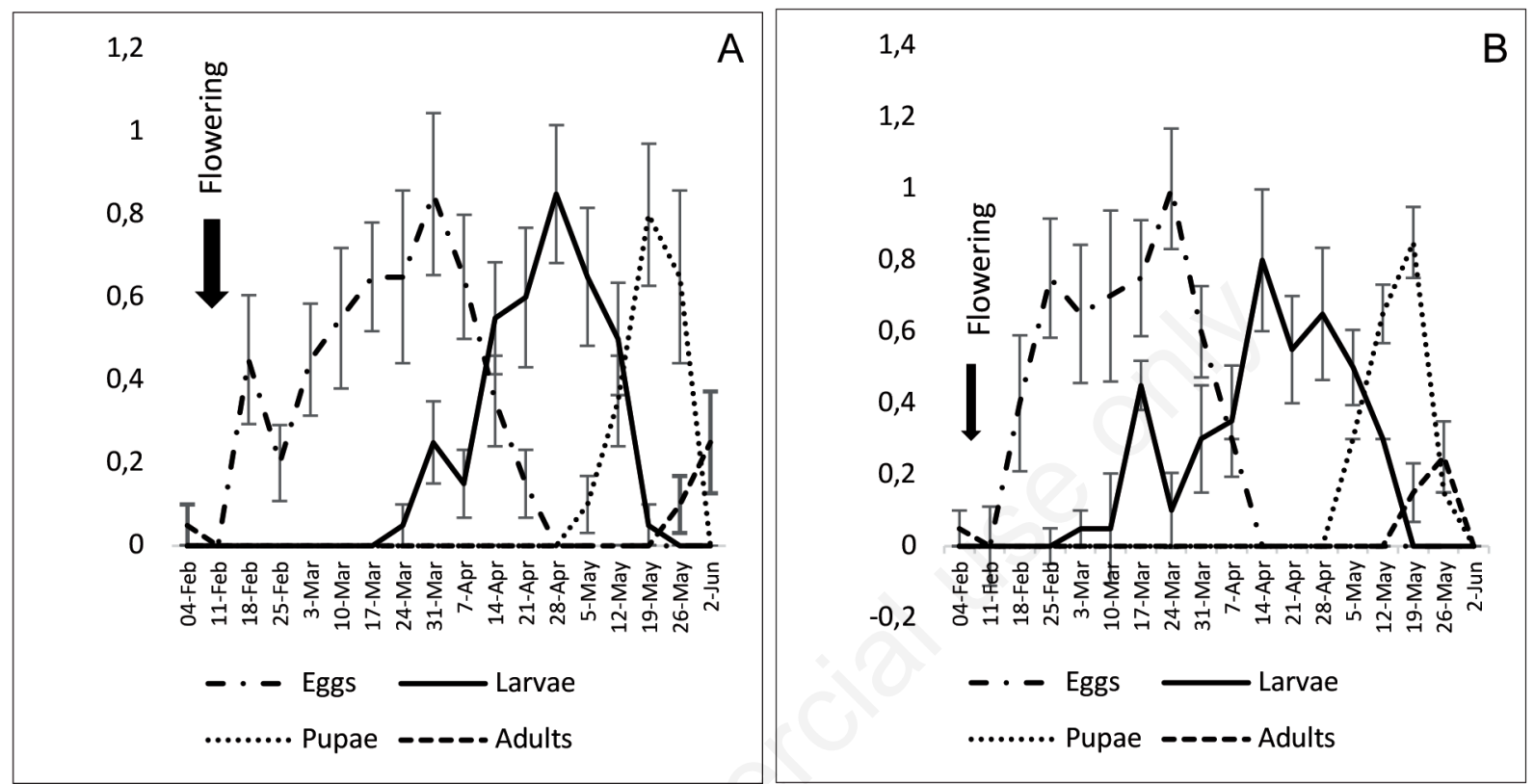

Figure 2. Mean number of eggs, larvae, pupae, and adults of $L$. algirus per 20 plants recorded on the local large-seeded variety Defes (Vicia faba var. major) (A) and small-seeded variety Alfia (Vicia faba var. minor) (B) during 2016, Douyet Station.

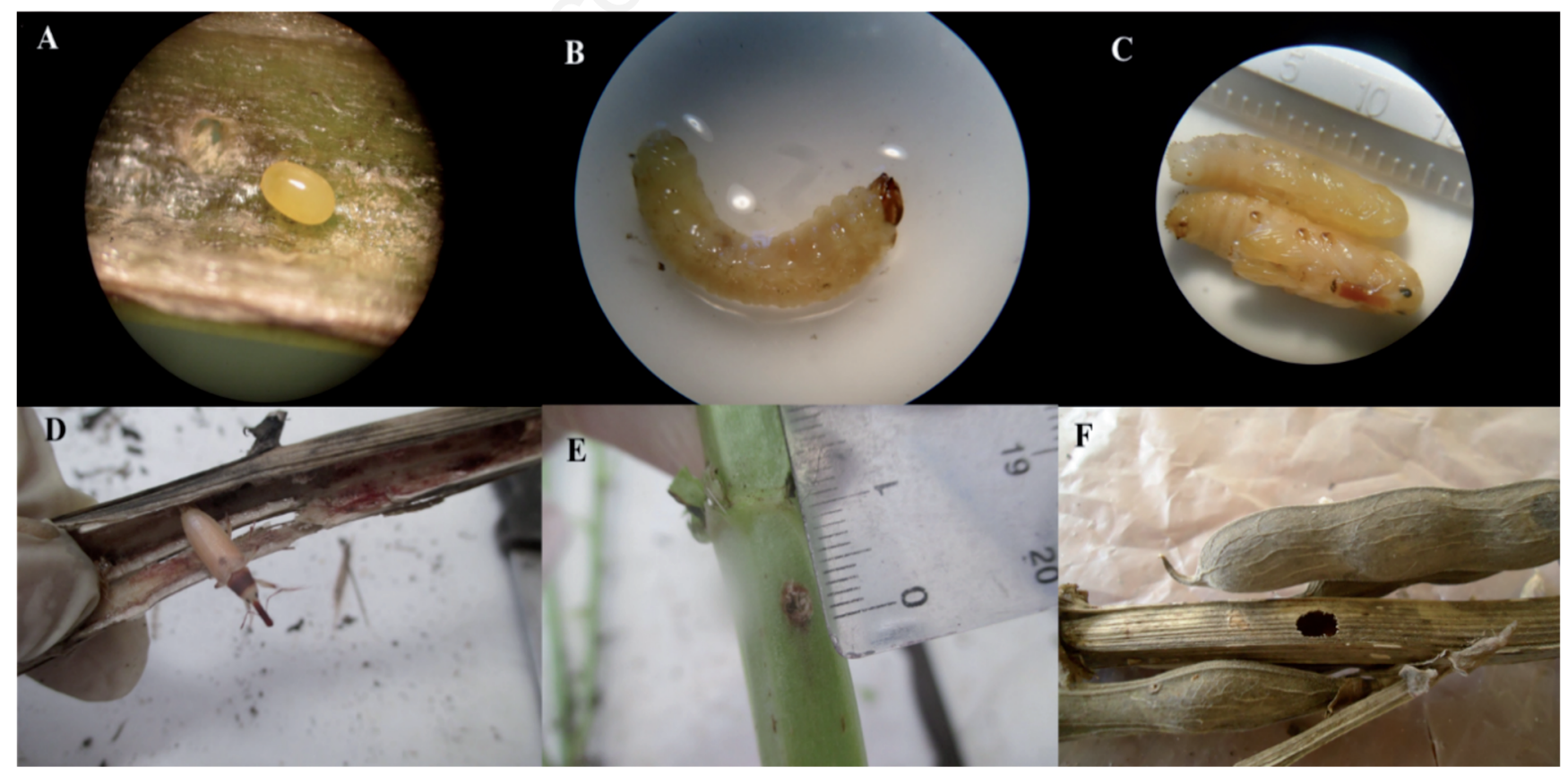

Figure 3. Stages of Lixus algirus. Egg (A); larva (B); pupa (C); emerged adult (D); laying hole (E); exit hole (F). 
March and reached the maximum value of $0.75 \pm 0.18$ eggs/ plant on 16 March (Figure 1B).

During 2016, the egg laying activity was recorded from 18 February to 21 April for the variety Defes. A strong egg laying activity was recorded with $0.85 \pm 0.19$ eggs/plant on 31 March (Figure 2C). Whereas the oviposition activity was recorded from 18 February to 07 April for the variety Alfia. The maximum number of eggs was recorded with $1 \pm 0.16$ eggs/plant on 24 March (Figure 2D). The egg laying activity decreases significantly from late March to early April.

\section{Larva populations}

After hatching, the larvae (Figure 3B) bore into and feed on stems of faba bean plants from late February to mid-May. The neonate larvae have a creamy white body, segmented, cylindrical and legless with a brown head and dark mouth parts. The larvae can reach between 1.5 to $28.4 \mathrm{~mm}$ in length, 0.8 to $4.5 \mathrm{~mm}$ in width (Table 1). They begin to feed on the tissues around the egg deposition and then tend to move towards the apex of the plant. After few days, the larvae return to the collar and then go back to the apex repeatedly. Their feeding tunnels inside the stem produce a dark brown exudate. The larval period development varies from 37 to 48 days, with an average of $42.03 \pm 2.82$ (Table 2).

The number of larvae gradually increased during March and peaked in April. During 2015, the larvae begin to appear on the local large-seeded variety Defes stems on March 09 and peaked with average $1.5 \pm 0.22$ larvae/ plant or 3 stems and $1.05 \pm 0.17$ per plant on 13 and 27 April, respectively. For the small-seeded variety Alfia, the larvae were first recorded in stems on 09 March and peaked twice with average $1.15 \pm 0.12$ larvae/plant on 30 March and 20 April, respectively (Figure 1A,B).

During 2016, the larvae fed within the variety Defes stems from 25 March and peaked with $0.85 \pm 0.16$ larvae/plant on 28 April, before declining gradually during the next months. While, the larvae appear earlier in stems of the small-seeded variety Alfia starting from 03 March and become most abundant in April. The larval peaks in the variety Alfia stems with $0.45 \pm 0.15$ larvae/plant and $0.80 \pm 0.16$ larvae on 17 March and 14 April, respectively.

\section{Pupation and the emergence of new generation adult weevils}

Upon completion of larval development, the mature larva generally moves towards the lower part of stem for pupation and become inactive. The pupae with projecting legs, rostrum, and elytra (Figure 3C) were found in the stem surrounded by their exudate left after larval feeding. The pupae are white to yellow in colour with elongated and stocky body. The females with longer and slightly thinner rostrum than males. In the early days, the pupa moves continuously, where the head faces the apex of the stem. The pupa can reach between 1.6 to $20 \mathrm{~mm}$ in length, 4 to $5 \mathrm{~mm}$ in width. The pupal period development lasts from 19 to 24 days, with average of $21.73 \pm 0.21$ (Table 2).

The earliest pupae found at the end of their feeding tunnels inside the stems was late April and peaked between early to midMay. During 2015, the pupae begin to appear within stems on the variety Defes stems on 27 April and peaked on 4 May with average $0.85 \pm 0.22$ pupae/plant. For faba bean variety Alfia, the pupae were first recorded in stems on 20 April and peaked with the average $0.9 \pm 0.09$ pupae /plant on 04 May (Figure 1A,B). During 2016, the first pupae were found within stems of the two varieties on 05 May and peaked with average $0.80 \pm 0.17$ pupae/plant on 19 May, respectively (Figures 3 and 4).

The neonate adults (Figure 3D) remain in the stems between 2 and 4 days. After that, they chew for few hours a perfectly circular exit hole of 5-6mm (Figure 3F) in diameter through the rostrum and start emerging in early June. Usually, the exit holes are situated in the upper part of the pupation cell. During this period, the adults maintain the same color (reddish brown in the dorsal part and creamy in the ventral side) which changes to become darker with time.

The data of 2015 (Figure 1A,B) showed that the first emerged adults were recorded on 11 May with the average of $0.35 \pm 0.15$ adult/plant for Defes variety. While, for the Alfia variety $0.05 \pm 0.03$ of emerged adult/plant was recorded on 04 May. During 2016, the first emerged adults were recorded on 26 May with $0.1 \pm 0.06$

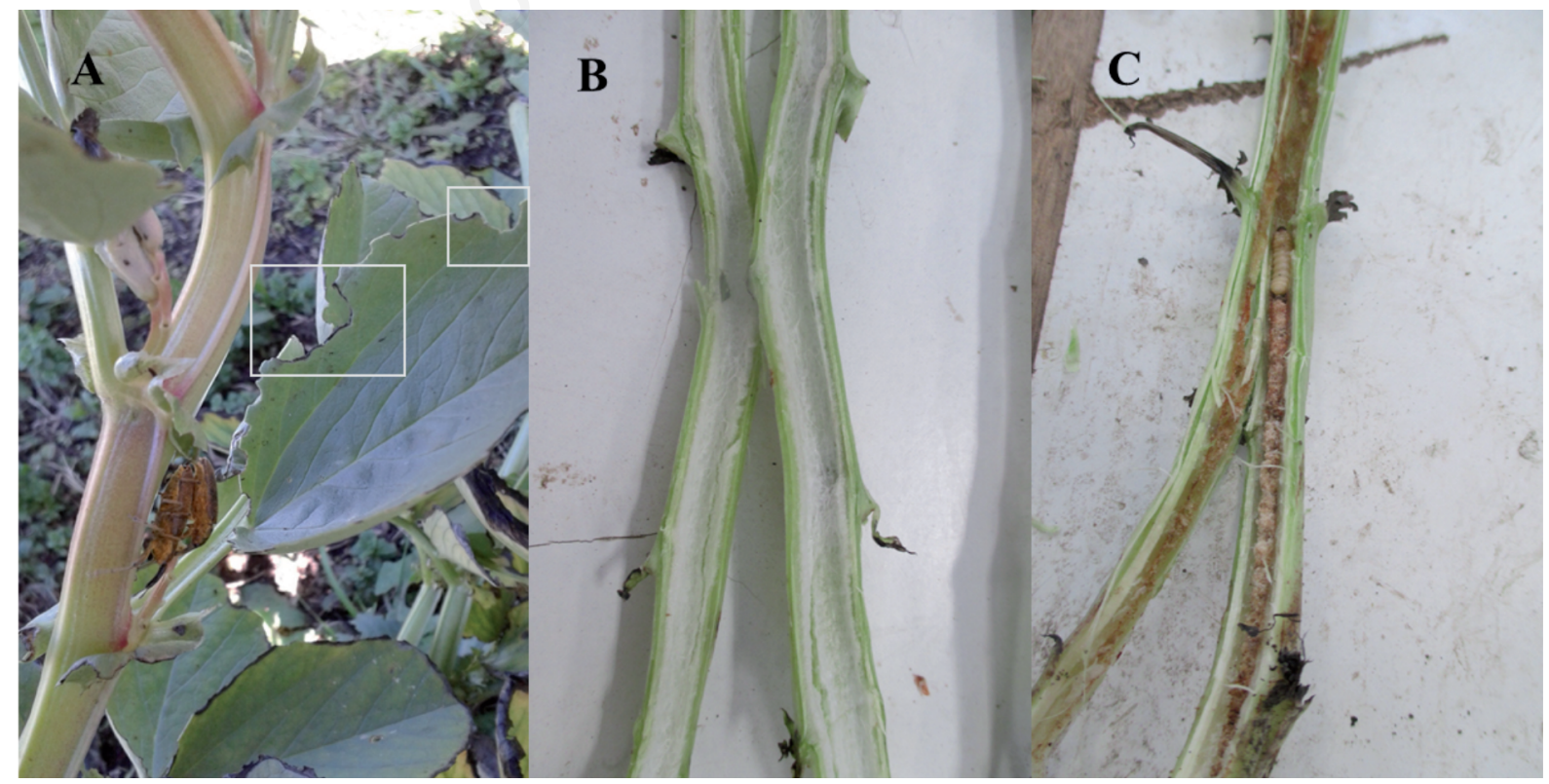

Figure 4. Injuries caused by adults and larvae of the L. algirus. Semi-circular notching caused the adults (A); uninfected faba bean stem (B); exudate caused by larval feeding (C). 
adult/plant for Defes variety. For Alfia variety, the first emerged adults were recorded one week earlier on 19 May with the average of $0.15 \pm 0.08$ adult/plant.

The results of the sex ratio of the field-emerged adults of $L$. algirus are given in Table 3. The ratio of the male to female insects tends to be $1: 1$ in both years, this could ensure less competition, so it can lead to an increase in mating frequency.

\section{Feeding preference of the overwintering generation of L. algirus}

The mean comparisons showed no significant difference in term of preference and feeding within stems in the two varieties during the two years (Table 4).

The data generated in 2015 revealed one significant difference $(\mathrm{p}<0.05)$ among the two varieties for the total number of larvae within the stems during March $(\mathrm{F}=8.58$, d.f. $=1, \mathrm{p}<0.043)$. Higher total numbers of larvae were recorded during March for Alfia with $51 \pm 2.08$ larvae. While, only $15 \pm 0.85$ larvae were obtained for Defes variety. However, no significant differences were found during the same year in term of the total adult exit holes for both varieties.

The total number of egg-laying holes per stems laid by L. algirus in both varieties do not differed significantly $(p<0.05)$ within the same months in both years. Although, there was one significant difference in total number of egg-laying holes among the two faba bean varieties during March $2016(\mathrm{~F}=20.51$, d.f. $=1, \mathrm{p}<0.011)$. The data showed more egg-laying holes recorded for Alfia variety with
$115 \pm 1.19$ and only $86 \pm 1.81$ recorded for Defes variety. However, no significant differences were found during 2016 for the total egg numbers in both varieties $(\mathrm{F}=1.23$, d.f. $=1, \mathrm{p}=0.33)$.

This comparison revealed no preference in term of egg laying or feeding of the stem borer between the large-seeded variety Defes and small-seeded variety Alfia.

\section{Symptoms and damage}

Adults L. algirus feed on the leaf margins of faba bean plants starting from late winter to late spring. They feed preferably on the upper soft leaves causing a typical marginal and semi-circular notching (Figure 4A); and sometimes they produce a dark excrement spot. The infested plants usually have a reduced total leaf area as a result of feeding damage caused by the adult weevils, which inhibits photosynthesis and can decrease plant growth.

The main damage is caused by the larvae feeding within stems especially for young faba bean plants. Their feeding tunnels inside the stem produce a dark brown exudate (Figure 4C). This feeding damage disrupt the movement of xylem and phloem. The liquid nutrients are cut off from the rest of the plant causing yellowing of leaves and growth-stunting.

\section{Effect of climatic factors on different stages of $L$. algirus population}

The data of the various environmental factors for the two crop seasons 2014-2015 to 2015-2016 are given in Table 5.

Table 3. The sex ratios of the field collected adults of $L$. algirus during 2015 and 2016.

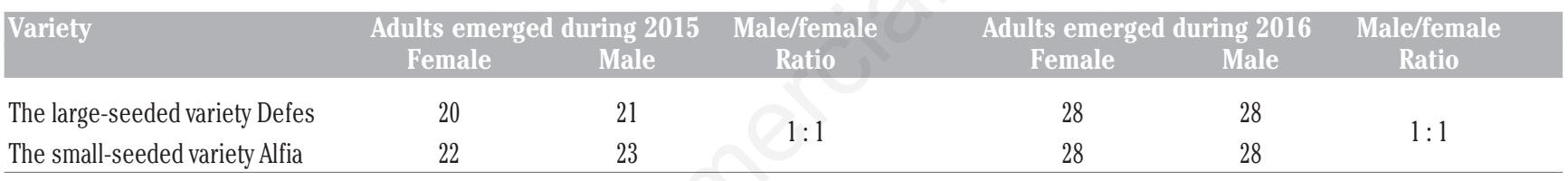

Table 4. Mean \pm standard error values of the total number of egg-laying holes, eggs, larvae, and adult exit holes in the local faba bean varieties Defes and Alfia during 2015 and 2016, Douyet Station.

\begin{tabular}{|c|c|c|c|c|c|}
\hline & Varieties & Number of egg-laying holes & Number of eggs & Number of larvae & Number of adult exit holes \\
\hline \multicolumn{6}{|c|}{2015} \\
\hline February & $\begin{array}{l}\text { Defes } \\
\text { Alfia }\end{array}$ & $\begin{array}{l}14 \pm 2.63 \\
12 \pm 1.98\end{array}$ & $\begin{array}{c}9 \pm 1.69 \\
10 \pm 1.60\end{array}$ & $\begin{array}{l}0 \\
0\end{array}$ & $\begin{array}{l}0 \\
0\end{array}$ \\
\hline March & $\begin{array}{l}\text { Defes } \\
\text { Alfia }\end{array}$ & $\begin{array}{c}94 \pm 1.46 \\
126 \pm 1.96\end{array}$ & $\begin{array}{l}74 \pm 1.14 \\
46 \pm 1.32\end{array}$ & $\begin{array}{c}15 \pm 0.85 \\
51 \pm 2.08 *\end{array}$ & $\begin{array}{l}0 \\
0\end{array}$ \\
\hline April & $\begin{array}{l}\text { Defes } \\
\text { Alfia }\end{array}$ & $\begin{array}{l}137 \pm 2.11 \\
104 \pm 2.04\end{array}$ & $\begin{array}{c}1 \pm 0.14 \\
0\end{array}$ & $\begin{array}{l}81 \pm 2.43 \\
71 \pm 1.16\end{array}$ & $\begin{array}{l}0 \\
0\end{array}$ \\
\hline May & $\begin{array}{l}\text { Defes } \\
\text { Alfia }\end{array}$ & $\begin{array}{l}160 \pm 1.51 \\
132 \pm 0.81\end{array}$ & $\begin{array}{l}0 \\
0\end{array}$ & $\begin{array}{c}1 \pm 0.14 \\
0\end{array}$ & $\begin{array}{l}28 \pm 2.02 \\
32 \pm 2.02\end{array}$ \\
\hline \multicolumn{6}{|c|}{2016} \\
\hline February & $\begin{array}{l}\text { Defes } \\
\text { Alfia }\end{array}$ & $\begin{array}{l}20 \pm 1.99 \\
34 \pm 2.91\end{array}$ & $\begin{array}{l}13 \pm 1,20 \\
23 \pm 2.03\end{array}$ & $\begin{array}{l}0 \\
0\end{array}$ & $\begin{array}{l}0 \\
0\end{array}$ \\
\hline March & $\begin{array}{l}\text { Defes } \\
\text { Alfia }\end{array}$ & $\begin{array}{c}86 \pm 1.81 \\
115 \pm 1.19 *\end{array}$ & $\begin{array}{l}63 \pm 0.74 \\
74 \pm 0.78\end{array}$ & $\begin{array}{c}6 \pm 0.54 \\
19 \pm 0.89\end{array}$ & $\begin{array}{l}0 \\
0\end{array}$ \\
\hline April & $\begin{array}{l}\text { Defes } \\
\text { Alfia }\end{array}$ & $\begin{array}{l}153 \pm 1.98 \\
151 \pm 1.15\end{array}$ & $\begin{array}{c}23 \pm 1.58 \\
6 \pm 0.75\end{array}$ & $\begin{array}{l}43 \pm 1.63 \\
47 \pm 0.95\end{array}$ & $\begin{array}{l}0 \\
0\end{array}$ \\
\hline May & $\begin{array}{c}\text { Defes } \\
\text { Alfia }\end{array}$ & $\begin{array}{l}162 \pm 1.46 \\
164 \pm 1.17\end{array}$ & $\begin{array}{l}0 \\
0\end{array}$ & $\begin{array}{l}24 \pm 1.82 \\
16 \pm 1.38\end{array}$ & $\begin{array}{l}3 \pm 0.42 \\
3 \pm 0.42\end{array}$ \\
\hline June & $\begin{array}{l}\text { Defes } \\
\text { Alfia }\end{array}$ & $\begin{array}{l}27 \pm 0.13 \\
37 \pm 0.07\end{array}$ & $\begin{array}{l}0 \\
0\end{array}$ & $\begin{array}{l}0 \\
0\end{array}$ & $\begin{array}{c}6 \pm 0.05 \\
10 \pm 0.07\end{array}$ \\
\hline
\end{tabular}

*Significant different value (ANOVA) in comparison with each variety within a month $(\mathrm{P}=0.05)$ 
The maximum and minimum temperature were negatively correlated, but not significant on the mean number of eggs for Defes and Alfia varieties in both years. The correlation between the total rainfall and egg numbers was positive and significant $(r=0.93)$ for both varieties, respectively. Whereas, a positive and non-significant correlation was found between mean relative humidity and egg numbers in both varieties over different years. The correlation between egg numbers and the mean relative humidity was positive, but statistically non-significant in both years.

The data from the present study showed that the number of larvae rises with the increase of all climatic factors in 2015. All the weather parameters were positively correlated, but not significant on larval population growth rates. In 2016, the mean number of larvae was negatively correlated, but non-significant with maximum and total rainfall for Defes variety. Whereas all weather parameters, except the mean relative humidity, were negatively correlated but non-significantly with the number of larvae within stems of Alfia variety.
During 2015, there was a significant negative correlation between mean relative humidity and mean number of pupae $(\mathrm{r}=$ $0,94^{*}$ and $\left.\mathrm{r}=-0,96\right)$, for Defes and Alfia varieties, respectively. Whereas, a negative and non-significant correlation was found between total rainfall and pupae numbers in both varieties tested. For the other weather parameters, the maximum and minimum temperature were positively correlated but non-significant on the number of pupae within stems.

\section{Host plants feeding preference of the new generation adult weevils $L$. algirus}

The mean number of feeding notches consumed by the adults L. algirus was different among the 10 host plants $(\mathrm{F}=47.42 ; \mathrm{df}=9$; $\mathrm{p}<0.001$ ).

Peach leaves were the most attractive and preferred by the adult weevils among all tree species with average number of feeding notches of $58.42 \pm 1.58$ (Figure 5). The almond leaves were the second most preferred with $37.71 \pm 2.11$. Whereas, no noticeable dam-

Table 5. Correlation analysis between climatic variables and developmental stages of L. algirus during 2015 and 2016 in Douyet Station.

\begin{tabular}{|c|c|c|c|c|c|c|}
\hline \multirow[t]{3}{*}{ Climate variables } & \multicolumn{6}{|c|}{ Stages of $L$. algirus } \\
\hline & Defes & Alfia & Defes & Alfia & Defes & Alfia \\
\hline & \multicolumn{2}{|c|}{ Eggs } & \multicolumn{2}{|c|}{ Larvae } & \multicolumn{2}{|c|}{ Pupae } \\
\hline \multicolumn{7}{|l|}{2015} \\
\hline Maximum temperature $\left({ }^{\circ} \mathrm{C}\right)$ & $-0,33$ & $-0,42$ & 0,19 & 0,04 & 0,85 & 0,92 \\
\hline Minimum temperature $\left({ }^{\circ} \mathrm{C}\right)$ & $-0,40$ & $-0,48$ & 0,20 & 0,02 & 0,86 & 0,93 \\
\hline Total rainfall (mm) & $0,93^{*}$ & $0,93 *$ & 0,02 & 0,50 & $-0,74$ & $-0,79$ \\
\hline Mean relative humidity (\%) & 0,32 & 0,40 & 0,03 & 0,15 & $-0,94^{*}$ & $-0,96^{*}$ \\
\hline \multicolumn{7}{|l|}{2016} \\
\hline Maximum temperature $\left({ }^{\circ} \mathrm{C}\right)$ & $-0,68$ & $-0,68$ & $-0,04$ & $-0,24$ & 0,24 & 0,24 \\
\hline Minimum temperature $\left({ }^{\circ} \mathrm{C}\right)$ & $-0,76$ & $-0,77$ & 0,04 & $-0,20$ & 0,35 & 0,35 \\
\hline Total rainfall (mm) & 0,22 & 0,44 & $-0,43$ & $-0,39$ & $-0,02$ & $-0,02$ \\
\hline Mean relative humidity (\%) & 0,72 & 0,70 & 0,09 & 0,31 & $-0,29$ & $-0,29$ \\
\hline
\end{tabular}

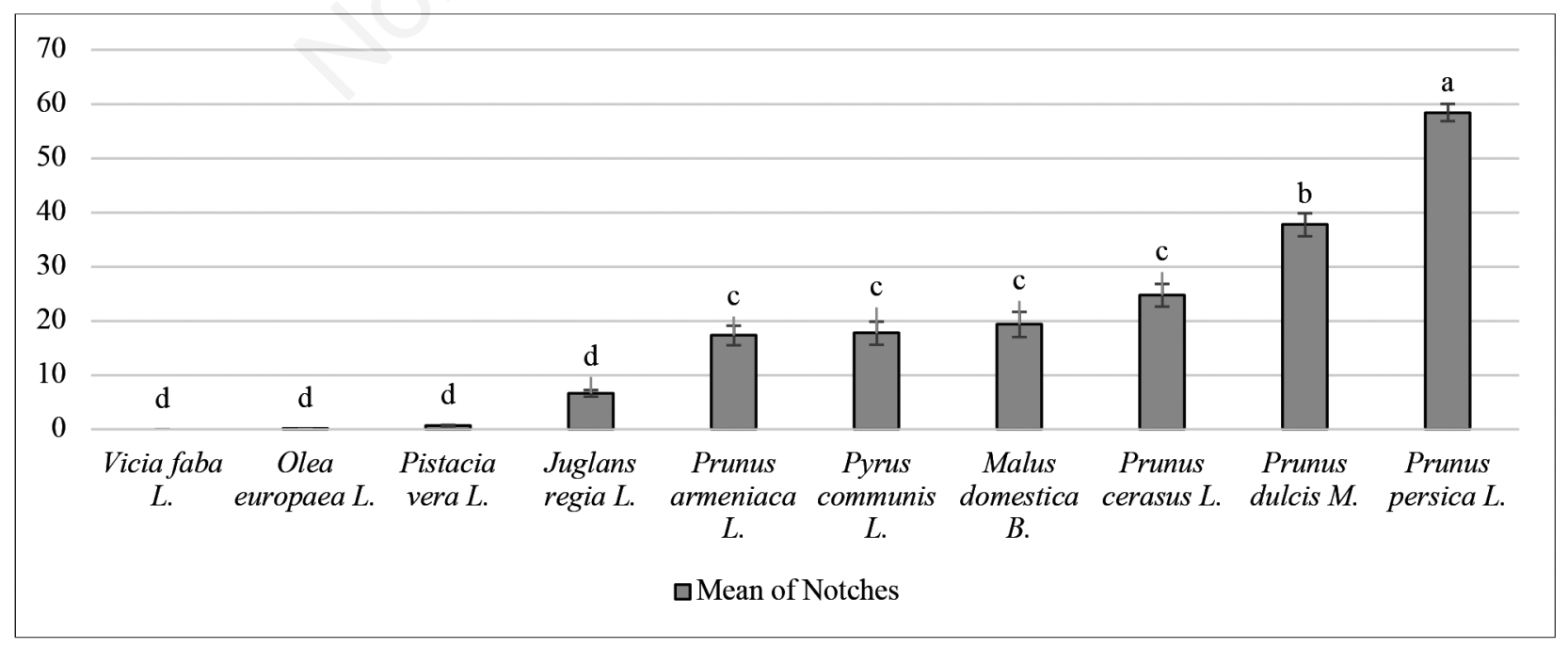

Figure 5. The mean number of feeding notches $( \pm \mathrm{SE})$ of the new generation adults on leaves of different tree species after $72 \mathrm{~h}$. Different letters over the bars indicate distinct mean value by the Newman-Keul's test $(p \leq 0.05)$. 
age in leaf area was detected in the control (Faba bean). Likewise, the feeding notches in the olive leaves $(0.08 \pm 0.03)$, Pistachio $(0.67 \pm 0.13)$ and Walnut $(6.62 \pm 0.60)$ were non-significant.

The rest of the Rosaceae leaves such as Dwarf cherry (24.71 \pm 2.09$)$, Apricot (17.29 \pm 1.80$)$, pear (17.71 \pm 2.13$)$ and apple $(19.33 \pm 2.31)$ were less preferred by the L. algirus compared to Peach and Almond. These results suggest that the emerged adults L. algirus feed mainly on leaves of Rosaceae trees after faba bean harvest.

Based on the survey conducted in Douyet and Marchouch regions on different plants and tree species during the summer and autumn times, most of emerged adults L. algirus were found feeding on various trees belonging to Rosaceae family, especially the peach and almond trees.

Depending on the availability of the host plants, they can feed on other families of trees, such as the walnut tree (Juglandacea family) and the Pistachio tree (Anacardiaceae family). This shows that the adult L. algirus is a polyphagous insect feeding on many plant species.

In general, the adults L. algirus feed less during the summer and early autumn period, on the different parts of the tree leaves causing notches around the leaf edges. Their movement in the trees remains very slow until late winter. They are never found hiding in soil cracks, under clods, or in debris on the ground.

\section{Effects of planting date, varieties, and location on faba bean stem borer infestation}

Analysis of variance summary of infested faba bean plants by L. algirus exposed to different planting dates, two local varieties and stations during 2017 and 2018 are shown in Table 6.

During 2017, there were significant effects of planting date on the infested plants by L. algirus $(\mathrm{p}<0.05)$ (Tables 6 and 7). In Douyet station, the mean number of infested faba bean plants of the small-seeded variety Alfia were lower at normal planting $(2 \pm 0.40)$ compared to late planting date $(7.25 \pm 1.70)$ (Table 7$)$. The effects of variety and variety $\times$ planting date interaction on square root number of infested plants were not significant $(\mathrm{p}>0.05)$. Also, the effects of stations and station $\times$ planting date interaction were not significant. The interaction of planting date $\times$ variety $\mathrm{x}$ station was not significantly different ( $\mathrm{p}>0.05$ ) (Table 6).

Further, there was no difference in term of infested plants occurring in early, normal, and late planted Alfia plots at Marchouch station. For the large-seeded variety Defes, the number of infested plants decreases from normal to late sowing in Douyet and Marchouch stations. However, the mean differences were not statistically significant according to Tukey's HSD test (Table 7).

The mean number of infested plants was generally higher in 2017 than in 2018. The maximum number of infested plants was recorded in 2017 for Alfia variety in Douyet station with $7.25 \pm 1.70$, when the maximum mean value in 2018 was recorded for Alfia with $1.42 \pm 0.28$ in Allal Tazi station (Tables 7 and 8). During 2018, there were significant effects of location (Marchouch and Allal Tazi stations) on the mean number of infested plants by L. algirus $(\mathrm{p}<0.001)($ Table 6$)$. The infested faba bean plants were greater in Allal Tazi than in Marchouch station for both varieties in different sowing dates.

Table 6. ANOVA describing the effect of planting date, variety, and station on square root number of infested plants by faba bean stem borer during 2017 and 2018.

\begin{tabular}{lccc} 
Source of variation & Df & Mean squares & $P<F$ \\
\hline 2017 & & & \\
Date (D) & 2 & 28.419 & 0.003 \\
Residual & 6 & 1.552 & \\
\hline Station (S) & 1 & 22.781 & 0.068 \\
Variety (V) & 1 & 0.100 & 0.847 \\
\hline D $\times V$ & 2 & 9.919 & 0.060 \\
$D \times S$ & 1 & 2.531 & 0.516 \\
\hline$V \times S$ & 1 & 1.531 & 0.612 \\
$D \times V \times S$ & 1 & 13.781 & 0.145 \\
\hline 2018 & & & \\
\hline Date $(D)$ & 1 & 0.2688 & 0.134 \\
Residual & 3 & 0.0645 & \\
\hline$S t a t i o n(S)$ & 1 & 9.5430 & $<.001$ \\
$V a r i e t y(V)$ & 1 & 0.5351 & 0.168 \\
\hline$D \times V$ & 1 & 0.1657 & 0.417 \\
$D \times S$ & 1 & 0.0344 & 0.576 \\
\hline$V \times S$ & 1 & 0.1649 & 0.221 \\
$D \times V \times S$ & 1 & 0.3415 & 0.078 \\
\hline
\end{tabular}

Table 7. Mean ( \pm SEM, $n=10)$ number of infested faba bean plants by L. algirus for three planting dates (early, normal to late planting) at Marchouch and Douyet Stations, 2017.

\begin{tabular}{|c|c|c|c|c|}
\hline \multirow{2}{*}{ Variety, Station/Planting date } & \multicolumn{2}{|c|}{ AALFIA, mean \pm SEM } & \multicolumn{2}{|c|}{ DEFES, mean \pm SEM } \\
\hline & Douyet & Marchouch & Douyet & Marchouch \\
\hline Early & & $1.75 \pm 0.47$ n.s. & & $2.25 \pm 0.75 \mathrm{n} . \mathrm{s}$ \\
\hline Normal & $2 \pm 0.40^{*}$ & $2.75 \pm 1.37$ & $4.25 \pm 0.47 n . s$. & $2.75 \pm 1.03$ \\
\hline Late & $7.25 \pm 1.70$ & $0.5 \pm 0.28$ & $3.25 \pm 0.94$ & $0.75 \pm 0.47$ \\
\hline
\end{tabular}

Early, seed sown from early to early December; Normal, seed sown from early December to early November, Late, Mid to Late December. *Significant at 5\%; n.s., nonsignificant differences according to Duncan's multiple range (DMR) test.

Table 8. Mean ( \pm SEM, $n=10)$ number of infested faba bean plants by $L$. algirus for three planting dates (early, normal to late planting) at Marchouch and Allal Tazi Stations, 2018.

\begin{tabular}{lcccc} 
Variety, Station/Planting date & \multicolumn{2}{c}{ ALFIA, mean \pm SEM } & \multicolumn{2}{c}{ DEFES, mean \pm SEM } \\
& Marchouch & Allal Tari & Marchouch & Allal Tari \\
Normal & $0.275 \pm 0.06 \mathrm{n} . \mathrm{s}$ & $1.42 \pm 0.28 \mathrm{n} . \mathrm{s}$ & $0.45 \pm 0.09 \mathrm{n} . \mathrm{s}$ & $1.02 \pm 0.30 \mathrm{n} . \mathrm{s}$ \\
Late & $0.425 \pm 0.13$ & $1.17 \pm 0.22$ & $0.125 \pm 0.06$ & $0.87 \pm 0.24$ \\
\hline
\end{tabular}


The effects of planting date and variety and their interaction on the number of infested plants were not significant $(p>0.05)$. The interaction of planting date $\times$ variety $\times$ station was not significant $(p>0.05)$. Lower faba bean infestation was recorded in 2018 for late sowing date, but this difference was not significant according to Duncan's multiple range (DMR) test (Table 8).

\section{Discussion}

The data on population dynamics of L. algirus (Figures 1 and 2) revealed that they follow a consistent pattern over the varieties and years, as peaks of the different insect stages were recorded on both cultivars from late February through late May.

The emergence of adult weevils occurred in late January at temperature $>9^{\circ} \mathrm{C}$ and feed on faba bean leaves. Notching of leaf margins caused by faba bean stem borer adults are much bigger than caused by pea leaf weevil, Sitona lineatus L (Liotta, 1963). The infestation of adult weevils increases gradually with increasing temperature and photoperiod. A similar observation was reported by Chakir (1992), who showed that the overwintering adults appear on minor faba bean plants in late January in Aïn El Aouda located in Rommani region. Cardona et al. (1985) reported that the adults of L. algirus leave diapause around midJanuary when minimum daily temperature can be as low as $5^{\circ} \mathrm{C}$ in Syria (Lattakia area).

The oviposition period lasted from mid-February to late April and peaking during mid to late March. The peak ranged from 0.75 to 1.1 eggs per plant. Similarly, Liotta (1963) reported in Italy (Sicily) that the females of $L$. algirus began to lay eggs on faba bean stems from early March until late April with a peak during mid-March. A similar observation was reported by Cardona et al. (1985) in Syria, who indicated that the adult females lay eggs mostly between February and March, but peaked earlier during mid-February. In Tunisia, mating and laying eggs lasts from March to mid-April (Hmem Bourissa et al., 2010). Generally, the females bore several holes into and lay one egg in the lower part of the stem. The egg laying activity decreases significantly from late March to early April. The eggs hatch over a period ranging from 11 to 15 days. In contrast, Liotta (1963) reported that the hatching period last longer in Italy from a minimum of 15 days to a maximum of 21 of hatching time. In Syria, the egg hatching takes an average of 18 days (Cardona et al.,1985). Through the two seasons of field monitoring in Morocco, the egg laying increased significantly when flowering starts. It seems that the egg laying activities vary depending on the phenological stage of the plant. These indications suggest the relative importance of floral volatiles cues from plant in enabling the L. algirus to recognize host plants from distance.

After hatching, the larvae bore into and feed on stems of plants from late February. The number of larvae gradually increases during March and peaked mostly in April, before declining gradually during the following months. The larval peaks ranged between 0.45 to 1.5 larvae per plant.

The present findings are in conformity with the results of Cardona (1985) who reported that the larval development occurs mostly during March to April. However, the highest larval population density was recorded in Italy between late April and early May (Liotta, 1963).

In the present study, the larval development time varies from 37 to 48 days, with an average of $42.03 \pm 2.82$. Similarly, the larval development lasts on average 45 days in Tunisia (Hmem Bourissa et al., 2010). Whereas, the average of the larval development time reached 45 to 50 days in Italy (Liotta, 1963). The duration of the total larval cycle takes a higher average of 55 days in Lattakia region in Syria (Cardona et al., 1985). Generally, one stem-boring larva occurs within a single stem. Two larvae may occur rarely together in a single stem, where one larva found in lower part of the stem and the other in the upper part. The larvae living in the same stem will sometimes kill each other. However, the larva does not attack the egg within the same stem. The cannibalistic behaviour of the L. algirus larvae were reported by Liotta (1963) and Chakir (1992). Usually only one larva occurs within the stem where it completes all its different stages. Cannibalism has also been reported for other Lixus species, such as Bitter Leaf Weevil (L. camerunus) and the Rhubarb Curculio L. concavus Say (Eluwa, 1979; Capinera, 2001).

The earliest pupae were found inside the stems in late April and peaked during May. The pupae peaks ranged between 0.8 to 0.9 pupae per plant. The pupal period development lasts from 19 to 24 days, with average of $21.73 \pm 0.21$. The pupal stage lasted less in Syria with an average of 17 days (Cardona et al., 1985) and between 10 to 17 days in Italy (Liotta, 1963).

In the present study, the neonate adults remain in the stems between 2 to 4 days, and these findings are in conformity with the results reported in Italy by Liotta (1963). In contrast, Cardona et al. (1985) reported that the new adults remain within faba bean stems for 10 to 12 days in Syria.

Our study showed that the entire life cycle (egg to adult) lasts approximately between 69 to 91 days with an average of 80 days. Liotta (1963) also reported a similar duration of life cycle which lasted 72 to 92 days. The complete cycle of L. algirus in Syria was 90.5 days (Cardona et al. (1985).

Our findings indicate that there is only one generation of $L$. algirus on faba bean. Throughout its area of distribution, Morocco, Tunisia, Syria, Italy and Spain, only one generation a year has been observed for this pest (Liotta, 1963; Isart, 1968; Cardona et al., 1985; Chakir, 1992; Boukhris-Bouhachem, 2013). However, 3 generations per year in Algeria and two in France were reported by Hoffmann (1963). Hoffmann $(1954 ; 1963)$ indicated that the number generation of $L$. algirus depend on weather conditions.

In the present study, seasonal variations of the weather factors affected the development and the trend in population fluctuations of $L$. algirus on both faba bean varieties. The number of eggs increases with the rise of precipitation and humidity. In addition, there was a significant negative correlation between mean relative humidity and mean number of pupae. Similarly, in certain coastal areas of Lebanon, Syria, and Turkey with high humidity and precipitation, higher Lixus infestation were found on faba bean varieties (ICARDA, 1982).

After faba bean harvest, the new emerged adults L. algirus were found feeding on various fruit trees belonging to Rosaceae family during the summer and early autumn period. The new generation adults are most attractive to Peach leaves followed by Almond leaves. The Dwarf cherry and Apricot were less preferred. Other families of trees could be host plants for the emerged adults L. algirus, such as the walnut tree (Juglandacea family) and the Pistachio tree (Anacardiaceae family). Similary, Liotta (1963) reported that the new adults can feed on Cardaceae, Malvaceae and Rosaceae including almond, peach and apricot tree leaves after faba bean harvest. The same author also reported that the new emerged adults survive the winter by hiding under the rocks.

In the present study, there is considerable evidence that the new emerged adults remain active during summer and autumn period feeding on different parts of the Rosaceae leave trees. In 
contrast, Chakir (1992) showed that the adults overwinter in the soil or in the dry stems of host plants. According to Isart (1967), adults can live up to 10-12 months feeding sporadically on beet and artichoke during summer and autumn.

Several authors described differently the diapause of several Lixus species. According to Trnka et al. (2016), adults of both species L. neglectus (Fremuth, 1983) and L. bituberculatus (Smreczyński, 1968) do not hibernate in the host plants, but most likely in the leaf litter, among dry plant debris or in the topsoil. In contrast, the species L. filiformis (Fabricius, 1781) overwinters as larva or pupa in the stems of host plants. Gültekin (2008) reported that L. myagri (Olivier, 1807) and L. circumcinctus (Boheman, 1835), realized their hibernation in the rootcrown of host plant. The same author reported several other Lixus species, which migrate before hibernation; this includes $L$. furcatus (Olivier, 1807) and L. obesus (Petri, 1904) and L siculus (Boheman, 1835) and L. korbi (Petri, 1904).

In addition, there was no difference in term of infested plants occurring in early, normal and late planted Alfia and Douyet varieties at different stations. The results showed that the number of infested plants decreases from normal to late sowing. However, the mean differences were not statistically significant. This finding is not consistent with Cardona et al. (1985) who showed that late planting date in Syria significantly decreased the percentage of stems infestation by L. algirus. Stems infested in early planting (early October) recorded about 35\% instead of only $10.6 \%$ recorded in late planting (late November-early December) in Terborl, (Lebanon). Similarly, in Lattakia (Syria), less infested stems were recorded in late planting (early January) with $4.1 \%$; instead of $51.2 \%$ recorded in early sowing (late October-early November). According to the same study, changes in planting dates have a great effect on oviposition patterns, with late planted crops showing significantly less infestation. However, the same authors do not recommend delaying planting date from early November to late December or early January, because of various factors including rainfall patterns, diseases, and weeds incidence. Furthermore, a wide range of management strategies for the control of faba bean stem borer had been tempted before. In Tunisia, application of carbofuran as seed treatment and foliar sprays of different insecticides did not reduce significantly stem borer infestations (Coers et al., 1983; Weigand \& Bishara, 1991). Efforts should be placed on host plant resistance to identify sources of resistance to this pest. Also, other sustainable control measures need to be tried as well, such semiochemicals for detection and monitoring or mass trapping using the attract and kill approach.

\section{Conclusions}

The present findings showed many similarities on the dynamic and field biology of the faba bean stem borer across the Mediterranean countries. It was found that the oviposition period extends from Mid-February to the end of April. The numbers of larvae gradually increased significantly and peaked in April. Larval feeding within stems caused significant damage. Only one generation is observed each year in Morocco. Abiotic factors like total rainfall and relative humidity influenced egg laying activity of $L$. algirus on different varieties of faba bean. However, the use of planting dates did not significantly impact the infestation level of $L$. algirus among the varieties tested and locations where the trials were conducted. The information generated in the present study would be helpful for the development of management options for the faba bean stem borer in Morocco.

\section{References}

AMANUEL G., KÜHNE R.F., TANNER D.G., VLEK P.L.G., 2000 - Biological nitrogen fixation in faba bean (Vicia faba L.) in the Ethiopian highlands as affected by $\mathrm{P}$ fertilization and inoculation. -Biol. Fert. Soils. 32: 353-359.

BARDNER R., 1983 - Pests of Vicia faba L. other than aphids and nematodes. In: The Faba Bean (Vicia faba L.). P.D. Hebblethwaite ed. - Butterworths, London, UK :371-390.

BOUKHRIS-BOUHACHEM S., 2013 - La recherche scientifique en entomologie depuis 1947 à l'INRAT: un itinéraire si riche et si glorieux, mais quel avenir?. - Annales de l'INRAT, numéro spécial centenaire de l'INRAT. 86: 191-212.

COERS P., TRAIA M., ZOUAGHI N., 1983 - Note d'information sur les pourcentages d'infestation des fèves et féveroles par les larves de Lixus spp. Notes techniques 85/1. Ministère de l'Agriculture, Station de la défense des Cultures du Nord-Beja. Projet Tuniso-Belge. Mimeographed hand-out

CARDONA C., JOUBI A., TAHHAN O., 1985 - Field biology of the faba bean stem borer, Lixus algirus L. (Coleoptera: Curculionidae) in Syria [Vicia faba]. -FABIS. Newsletter. $12: 14-17$.

CHAKIR S., 1992 - Observation préliminaire sur la biologie. Les dégâts de Lixus algirus L. (Col. Curculionidae) sur fèverole au Maroc. - Inst. Agron. Vet. 12: 41-44.

CAPINERA J.L., 2001 - Handbook of Vegetable Pests. - Academic Press, San Diego: 729 pp.

CREPONA K., MARGET P., PEYRONNET C., CARROUÉE B., ARESE P., DUC G. 2010 - Nutritional value of faba bean (Vicia faba L.) seeds for feed and food. - Field. Crops. Res. 115: 329-339.

DIEKMANN M., 1982 - Survey on pests and diseases of faba bean (Vicia faba) in Egypt, Morocco and Tunisia. - FABIS. Newsletter. 4: 44-46.

DARA SK., 2019 - The new integrated pest management paradigm for the modern age. - J. Integr. Pest Manag. 10: 1-12.

ELUWA MC., 1979 - Biology of Lixus camerunus Kolbe (Coleoptera Curculionidae): a major pest of edible vernonias (Compositae) in Nigeria. - Rev. Zool. Bot. Afr. 93: 223-240.

FAO., 2016 - FAOSTAT. Food and Agriculture Organization of the United Nations. http://www.fao.org/faostat, Accessed: 30 January 2016.

GÜLTEKIN L., 2008 - Hibernation places and behavior of the some weevil species (Coleoptera: Curculionidae). - Caucasian Entomological. Bulletin. (CEB). 4(2): 209-213.

HOFFMANN A., 1954 - Coléoptères Curculionidae, 2e partie. Faune de France 59. - Fédération Française des Sociétés de Sciences Naturelles, Paris : 1208 pp.

HOFFMANN A., 1958. - Coléoptères Curculionidae, 3e partie. Faune de France 62. - Fédération Française des Sociétés de Sciences Naturelles, Paris : 632 pp.

HOFFMANN A., 1963 - Familie des Curculionides - Sous-Familie des Cleoninae. In : Balachowsky, A.S. ed. Entomologie Appliqée a l’agriculture. Traité. Tome 1. Coléoptères. Vol. 2. Masson et Cie, Paris : 953-981.

HMEM BOURISSA M., BOUKHRIS-BOUHACHEM S., KRIDA G., SOUISSI R., KHARRAT M., 2010 - Incidence et Cycle Biologique d'un Ravageur de la fève Lixus algirus L. (Coleoptera: Curculionidae). Association Tunisienne des Sciences Biologiques. Proceedings du 21ème Forum International des Sciences Biologiques, 15 - 18 Mars, Mahdia, Tunisie 
ISART J., 1967 - El Lixus de las habas, Lixus algirus L., (Col., Curculionidae). - Graellsia 23: 171-204.

ICARDA., 1982 - Food legumes improvement. In: Annual report. - Aleppe, Syria: 115.

KUSCHEL GA., 1995 - Phylogenetic Classification of Curculionoidae to Families and Subfamilies. Entomol. Soc. Wash. 14: 5-33.

KHAN H.R., PAULL J.G., SIDDIQUEC K.H.M., STODDARD F.L., 2010 - Faba bean breeding for drought-affected environments: A physiological and agronomic perspective. - Field. Crops. Res. 115: 279-286.

LIOTTA G., 1965 - Observations on Lixus algirus L. (broad-bean stem borer). Bollettino dell'Istituto di entomologia agraria e dell'Osservatorio di fitopatologia di Palermo .5:105-128.

METEOBLUE, 2018 - http://www.meteoblue.com, Accessed :10 Jan 2018

MANZOOR Q., 2013 - Sustainable Water Use Securing Food Production in Dry Areas of the Mediterranean Region SWUPMED Project; Deliverable 4.2: Identification of the implications of supplemental and deficit irrigation (Report).

MAALOUF F., NAWAR M., HAMWIEH A., AMRI A., ZONG X., SHIYING B., YANG T., 2013 - Faba Bean, in "Genetic and Genomic Resources of Grain Legume Improvement”. Amsterdam, Netherlands. Elsevier. 113-136.
SAKR B., 1991 - The status of faba bean production in Morocco. In: Cubero J.I. ed., Saxena M.C. ed. Present status and future prospects of faba bean production and improvement in the Mediterranean countries. CIHEAM, Zaragoza. Options Méditerranéennes: Série A. Séminaires Méditerranéens; n. 10: 153-157

TRNKA F., STEJSKAL R., SKUHROVEC J., 2016 - The morphology of the immature stages of two rare Lixus species (Coleoptera, Curculionidae, Lixinae) and notes on their biology. - ZooKeys. 604: 87-116.

WEIGAND S., BISHARA S.I., 1991 - Status of insect pests of faba bean in the Mediterranean region and methods of control. In: Cubero J.I. ed., Saxena M.C. ed. Present status and future prospects of faba bean production and improvement in the Mediterranean countries. CIHEAM, Zaragoza. Options Méditerranéennes: Série A. Séminaires Méditerranéens; n. 10: 67-74.

YIGEZU Y.A., EL-SHATER T., BOUGHLALA M., BISHAW Z., NIANE A., AW-HASSAN A., 2018 - Is there an economic case for legume-cereal rotation? A case of faba-beans in the Moroccan wheat-based production systems. In: International Association of Agricultural Economists. Presented at the 30th International Conference of Agricultural Economists, Vancouver. Vancouver, British Columbia. 32pp. 